\title{
Stigma during COVID-19 pandemic among healthcare workers in greater Jakarta metropolitan area: a cross-sectional online study
}

DOI: https://doi.org/10.22435/hsji.v12i1. 4754

Ika Saptarini, Novianti, Anissa Rizkianti, Iram Barida Maisya, Suparmi, Ginoga Veridona, Ning Sulistiyowati, Sudikno

Center for Research and Development of Public Health Efforts, National Institute of Health Research and

Development Ministry of Health, Republic of Indonesia

Corresponding author: Ika Saptarini

Email: dr.ikasaptarini@gmail.com

Received: April 6, 2021; Revised: May 25, 2021; Accepted: June 4, 2021.

\begin{abstract}
Background: COVID-19, which started in Wuhan, has become a global pandemic leading to a new global risk to human health. Lack of information or misinformation about COVID-19 can lead to stigmatization, including for health workers. This study aims to determine the stigmatization among health workers during the COVID-19 pandemic within the Greater Jakarta Metropolitan Area.

Methods: This study was a cross-sectional study conducted online using Google Forms in the Jabodetabek area. The questionnaire's link was distributed through social media, including Whatsapp, Facebook, Twitter, and Instagram. The study sample is health workers who live in Jabodetabek and carry out health practices. Stigma is measured using four dimensions: personalized stigma, disclosure concerns, public attitudes, and negative self-image.

Result: The negative self-image dimension is the dimension most felt by health workers. More than half of health workers agreed that during the COVID-19 pandemic, they put their families at risk because of their status as health workers. The stigma of health workers who work in hospitals is higher than that of non-hospital health workers, such as health centers, clinics, and laboratories.

Conclusion: There was any stigmatization among healthcare workers in Greater Jakarta Metropolitan Area. Stigmatization was higher among healthcare workers who work in hospitals compared to those who work in nonhospitals. Some efforts should be made to reduce stigmatization among health workers, such as provide correct information to the public, equip health personnel with adequate personal protective equipment, and give incentives periodically to the health workers. (Health Science Journal of Indonesia 2021;12(1):6-13)
\end{abstract}

Keywords: stigma, COVID-19, healthcare workers, Greater Jakarta Metropolitan Area

\begin{abstract}
Abstrak
Latar belakang: COVID-19 yang bermula dari Wuhan telah menjadi pandemi global yang mengancam kesehatan umat manusia. Kurangnya informasi atau informasi yang salah mengenai COVID-19 dapat menyebabkan adanya stigmatisasi termasuk terhadap tenaga kesehatan. Penelitian ini menilai adanya stigmatisasi terhadap tenaga kesehatan selama pandemi COVID-19 di wilayah Jabodetabek.
\end{abstract}

Metode: Penelitian ini merupakan penelitian potong lintang dan dilakukan secara daring menggunakan Google Form di wilayah Jabodetabek. Tautan pengisian kuesioner disebarkan melalui media sosial seperti Whatsapp, Facebook, Twitter dan Instagram. Sampel studi adalah tenaga kesehatan yang tinggal di Jabodetabek dan melakukan praktik kesehatan. Stigma diukur menggunakan empat dimensi yaitu personized stigma, disclosure concerns, concerns about public attitudes dan negative self-image.

Hasil: Dimensi negative self-image merupakan dimensi yang paling dirasakan oleh tenaga kesehatan. Lebih dari separuh tenaga kesehatan setuju bahwa selama pandemi COVID-19 mereka membahayakan keluarga mereka karena status mereka sebagai tenaga kesehatan. Stigma pada tenaga kesehatan yang bekerja di rumah sakit lebih tinggi disbanding tenaga kesehatan yang bekerja bukan di rumah sakit seperti puskesmas, klinik dan laboratorium.

Kesimpulan: Terdapat stigmatisasi pada petugas kesehatan di jabodetabek. Stigmatisasi lebih tinggi di antara petugas kesehatan yang bekerja di rumah sakit dibandingkan dengan mereka yang bekerja tidak di rumah sakit. Beberapa upaya yang perlu dilakukan untuk mengurangi stigmatisasi di kalangan petugas kesehatan, seperti memberikan informasi yang benar kepada masyarakat, melengkapi tenaga kesehatan dengan alat pelindung diri yang memadai, dan memberikan insentif kepada mereka secara berkala. (Health Science Journal of Indonesia 2021;12(1):6-13)

Kata kunci: stigma, COVID-19, tenaga kesehatan, jabodetabek 
Novel Coronavirus disease (COVID-19), which began in Wuhan, China, has become a pandemic disease, leading to a new global risk to human health. COVID-19 is a novel infectious disease spread by coughing and sneezing, close personal contact with someone infected with the virus, and touching an object or surface contaminated with the virus. On 11 January 2020, after testing for pathogenic nucleic acids, China reported 41 cases of severe pneumonia due to infection of the new coronavirus (SARSCoV-2) in humans for the first time. COVID-19 spread to more than one hundred countries, with a total of more than 5,000,000 people infected. World Health Organization declared a new coronavirus pandemic on 11 March, 2020. ${ }^{1}$ The first case of COVID-19 in Indonesia was detected on 2 March 2020, involving two women contacted tourists from Japan. $^{2}$

Greater Jakarta Metropolitan Area (Jabodetabek) is the biggest and the most strategic metropolitan in Indonesia. Thus, these areas tended to have high population densities. Greater Jakarta Metropolitan Area consists of Jakarta, Indonesia's capital, and eight other cities, including Bogor City, Bogor Regency, Depok City, Tangerang City, South Tangerang City, Tangerang Regency, Bekasi City, and Bekasi Regency. ${ }^{3}$ Greater Jakarta Metropolitan Area is the area with the highest COVID-19 cases in Indonesia. The COVID-19 pandemic was centered in the Jakarta Capital Special Region (DKI Jakarta), which contributed over half of Indonesia's total number in the first month; two-thirds of the surrounding urban districts that make up the Greater Jakarta Metropolitan Area was included. Some health facilities for COVID-19 treatment were also built in Greater Jakarta Metropolitan Area, such as COVID-19 Emergency Hospital (Rumah Sakit Darurat Wisma Atlet) and field hospital. Some hospitals also function as a hospital for treating COVID-19 patients in this area. ${ }^{4}$

Scientists, researchers, and medical professionals worldwide are still working at a breakneck pace to figure out how to deal with this virus's novelty. Stigma is described as "the negative association between an individual or group of people who share certain characteristics and a specific disease" in the sense of health. Fear, anxiety, and a lack of information about a disease that causes severe symptoms or death can stigmatize patients who have the disease or treat them. Isolation, failure to provide service, abuse, and bullying are examples of stigmatized communities' discriminatory practices. ${ }^{5}$ Previously, stigma has been associated with different infectious diseases such as Ebola, SARS, AIDS, and Tuberculosis. Stigma has arisen since specific populations are targeted as the reason for COVID-19 pandemic. ${ }^{6}$ For example, in studies conducted in Taiwan and Hong Kong during the 2003 outbreak of Severe Acute Respiratory Syndrome (SARS), 20-49 percent of healthcare workers involved in the treatment of SARS patients was reported being shunned, avoided, or otherwise stigmatized by people in their group for fear of being infected with the SARS coronavirus. ${ }^{8,9}$

Healthcare workers had complex and contradictory thoughts and feelings about balancing their positions as healthcare professionals and family members, feeling professional obligation and fear of this emerging disease, related coronavirus patients, and remorse about potentially infecting their families. Working with potentially contagious patients resulted in a great deal of shame. Contagion elicits a wide variety of feelings, values, biases, stereotypes, and stigmas. Emotions play a crucial role in these situations, distorting expected or factbased decisions. The obligation owed by physicians, nurses, and healthcare staff to their patients and the underlying behaviors induced by the contagion are incompatible. ${ }^{10}$

Healthcare workers were hailed as heroes in the national press and by government officials during the COVID-19 pandemic. People around the world have made public applause for healthcare workers a nightly ritual. ${ }^{11}$ Is this to suggest that, unlike SARS, healthcare workers' stigmatization will not be a concern during the COVID-19 pandemic? The present study aimed to investigate healthcare workers' stigmatization during the COVID-19 pandemic in Greater Jakarta Metropolitan Area.

\section{METHODS}

A cross-sectional web-based survey was carried out by using google forms. Data collection was conducted from 30 April to 2 May 2020 to collect the information. The Institutional Review Boards approved this study of the National Institute of Health Research and Development, Ministry of Health. This study's sample was healthcare workers who lived in Greater Jakarta Metropolitan Area and running 
healthcare services. A structural questionnaire link was sent to Greater Jakarta Metropolitan Area health workers through social media, including WhatsApp, Facebook, Instagram, and Twitter. Inclusion criteria were as follows: health workers aged 15 years old and above, living in Greater Jakarta Metropolitan Area and accessing the internet who voluntarily participated in this study. Prior to data collection, respondents were given a detailed summary of the survey and asked to sign an online informed consent form. Respondents were excluded if they could not complete the online survey independently. The respondents filled out a Google Form-connected questionnaire, which was then submitted to the final database and downloaded as a Microsoft Excel sheet. A total of 277 respondents provided complete information regarding the survey.

A self-made questionnaire was used to collect respondents' demographic information, including residence, gender, age, marriage. In addition, a new questionnaire was developed to measure stigma regarding COVID-19 pandemic among healthcare workers. Finally, a questionnaire trial was conducted to validate the questionnaire. Ethical clearance provided by the Ethics Commission of the NIHRD, $\mathrm{MoH}$ under the letter number of LB.02.01/2/ $\mathrm{KE} / 327 / 2020$.

\section{Measurement}

Some previous studies showed that stigma was challenging to measure and analyze. It is difficult to determine which stigma construct is being assessed when items are written this way. One of the problems to measure stigmatization is the most suitable tools and practices in dealing with stigma? ${ }^{12,13}$ We develop a new instrument to measure stigmatization among healthcare workers during COVID-19 pandemic. We adopted a short version of the HIV stigma scale to measure stigma among healthcare workers. First, the instrument including twelve questions. We conducted an instrument trial to assess the instrument validity and reliability. Then we conducted a validity and reliability test. Three questions were dropped due to poor validity. The final questionnaire consists of nine (9) questions regarding internalized stigma with fair internal reliability (Cronbach alpha, $\alpha: 0.69)$. Stigma was measured in four dimensions: personalized stigma, disclosure concerns, concerns about public attitudes, and negative self-image. Nine questions were used to measure stigma, including two questions about personalized stigma, two questions about disclosure concerns, two questions about public attitudes, and three questions about negative self-image. We make point one (1) if the respondent agrees and zero (0) if disagree. The stigma scale was a continuous variable, and it was calculated the sum of nine questions about stigma. Higher scores indicated higher levels of stigmatization levels.

We also collected some information regarding the associated stigma among healthcare workers, including demography variables (age, residence, gender, marital status), healthcare worker, workplace type, and vulnerable household member. The households are categorized to have a vulnerable group if there are any pregnant women, babies, children, or elderly.

\section{Statistical analysis}

All data were subsequently imported into and analyzed using STATA 15.1 SE. The results were presented in texts and tables. Univariate analysis was conducted to describe participant characteristics. Linear regression analysis was used to assess the strength of the relationship and monitor for possible confounding variables, and significance was set at a p-value. The p-value below 0.05 was considered to be associated with stigma regarding COVID-19 pandemic among healthcare workers. Before we construct the final model, a heteroscedasticity test was performed to assess data distribution. The heteroscedasticity test showed that data have homoscedasticity so that linear regression can be performed to the final analysis.

\section{RESULTS}

\section{Characteristics of the respondents}

Table 1 presents the demographic and work-related characteristics of the sample. Most of respondents highly represented groups of nurses $(41.2 \%)$, midwives $(18.8 \%)$, and doctors (18.1\%). The majority of respondents $(64.6 \%)$ were from outer Jakarta, female $(84.1 \%)$, and being married (60.7\%). More than half of the respondents $(52.4 \%)$ were work in non-hospitals (primary health centers, clinics, and laboratories). 
Table 1. Demographic and work-related characteristics of respondents $(\mathrm{n}=277)$

\begin{tabular}{|c|c|c|}
\hline Variables & $\mathrm{n}$ & $\%$ \\
\hline \multicolumn{3}{|l|}{ Age group } \\
\hline $15-29$ years & 135 & 48.7 \\
\hline $30-49$ years & 132 & 47.7 \\
\hline $50+$ years & 10 & 3.6 \\
\hline \multicolumn{3}{|l|}{ Residence } \\
\hline Jakarta & 98 & 35.4 \\
\hline Outer Jakarta & 179 & 64.6 \\
\hline \multicolumn{3}{|l|}{ Sex } \\
\hline Male & 44 & 15.9 \\
\hline Female & 233 & 84.1 \\
\hline \multicolumn{3}{|l|}{ Marital status } \\
\hline Never married & 104 & 37.6 \\
\hline Divorce & 5 & 1.8 \\
\hline Married & 168 & 60.7 \\
\hline \multicolumn{3}{|c|}{ Type of healthcare worker } \\
\hline Doctor & 50 & 18.1 \\
\hline Nurse & 114 & 41.2 \\
\hline Midwives & 52 & 18.8 \\
\hline Others* & 61 & 22.0 \\
\hline \multicolumn{3}{|l|}{ Type of workplace } \\
\hline Hospital & 132 & 47.7 \\
\hline Non-hospital** & 145 & 52.4 \\
\hline \multicolumn{3}{|c|}{ Vulnerable household member } \\
\hline Any & 122 & 44.0 \\
\hline None & 155 & 56.0 \\
\hline
\end{tabular}

\section{Stigma among healthcare workers regarding COVID-19 pandemic}

We measured stigma in four dimensions (personalized stigma, disclosure concern, concern about public attitude, and negative self-image). Table 2 presents descriptive results regarding stigma among healthcare workers in Greater Jakarta Metropolitan Area. Negative self-image was the most dimension of the stigma that affecting healthcare workers. More than half $(67.9 \%)$ respondents agree that they were endangering their families because of their profession as healthcare workers. Almost one-third of the respondents (28.2\%) agree that people's attitudes to health workers make them feel worse about themselves. There were higher levels of agreement with questions about disclosure concerns. For example, $39 \%$ of respondents agree that healthcare workers worry that people will disclose their professional status. On the other hand, a few $(16.3 \%)$ respondents agree to keep their professional status a secret.

Concern about public attitude also affects some healthcare workers. About one-fifth (23.5\%) agree that people believe that health workers must have contracted COVID-19. Also, one fifth (21.7\%) of respondents agree that community member ostracizes healthcare workers. A few respondents agreed on personalized stigma. For example, 16.6\% of respondents agree that people avoid them due to their professional status. Also, $9.4 \%$ of respondents agree that they lose their friends due to their profession as healthcare workers.

\section{Factors associated stigma among healthcare workers}

Overall, the mean stigma score among healthcare workers in Greater Jakarta Metropolitan Area was 2.38 (SD: 1.98). The stigma score was higher among younger age groups, healthcare workers who lived in Jakarta, doctors, and healthcare workers who work in hospitals. We use linear regression to determine the factors associated with stigma among healthcare workers in Greater Jakarta Metropolitan Area. We found that type of workplace was associated with stigma among healthcare workers. Those healthcare workers who work in the hospital had an average of 0.80 units higher stigma scores when compared to those healthcare workers who work in non-hospital (primary health center, clinic, or laboratory). However, the average stigma of doctors and other types of healthcare workers was not significantly different. In addition, healthcare workers' average stigma was not significantly different regarding demography (age, residence, sex, marital status, and vulnerable household member). 
Table 2. Frequencies and percent for survey measures

\begin{tabular}{|c|c|c|}
\hline \multirow{2}{*}{ Variables } & \multicolumn{2}{|c|}{ Frequency $(\%)$} \\
\hline & Agree & Disagreed \\
\hline \multicolumn{3}{|l|}{ Personalized stigma } \\
\hline Feeling that people avoid me & 16.6 & 83.4 \\
\hline Losing friends and fear of rejection & 9.4 & 90.6 \\
\hline \multicolumn{3}{|l|}{ Disclosure concerns } \\
\hline Worrying that others will disclose my professional status & 39.0 & 61.0 \\
\hline Keeping my professional status a secret & 16.3 & 83.8 \\
\hline \multicolumn{3}{|l|}{ Concerns about public attitudes } \\
\hline People believe that healthcare workers must have contracted COVID-19 & 23.5 & 76.5 \\
\hline Community member ostracizes healthcare workers & 21.7 & 78.3 \\
\hline \multicolumn{3}{|l|}{ Negative self-image } \\
\hline Endangering family because of my profession as a healthcare worker & 67.9 & 32.1 \\
\hline Feeling guilty to the family due to my profession & 15.9 & 84.1 \\
\hline People's attitudes to health worker make me feel worse about myself & 28.2 & 71.8 \\
\hline
\end{tabular}

*Other: nutrition, laboratory staff, pharmacies

** Non-hospital: primary health center, clinic, laboratory

Table 3. Multiple linear regression model predicting healthcare workers' stigma regarding COVID-19 pandemic 


\section{DISCUSSION}

Stigmatization of healthcare workers is linked to both mental and physical health. Healthcare workers who expected higher stigmatization levels showed higher psychological distress levels, which predicted higher somatic symptoms. Healthcare workers are at high risk to infected with the virus due to their professional status. ${ }^{10}$ It is well known how healthcare staff and ambulance crews in some Latin American, African, and European countries became objects of stigma and prejudice in the most affected areas. ${ }^{14}$ Some healthcare workers felt humiliated in Indonesia because of their status as healthcare workers, such as doctors and nurses, or served in the COVID-19 hospital. ${ }^{15}$

Even though healthcare workers have a higher risk of infection with COVID-19 than the general population, no health authority or government has recommended that healthcare workers be removed from their communities or families during the COVID-19 pandemic, to our knowledge. However, this situation made the healthcare workers experience a negative self-image, such as endangering their family and feeling guilty to their family due to their professional status. ${ }^{11}$ This study found a similar finding that negative self-image among healthcare workers was the highest dimension of the stigma that affects healthcare workers.

This study also found that healthcare workers concern about public attitudes. How society treats healthcare workers during COVID-19 pandemics made them worse. That is people who tend to stigmatize (fear and avoid) healthcare workers. The breadth and limits of fear and avoidance are a topic that needs to be investigated further. People who have a high level of fear and avoidance of healthcare workers may also avoid other groups of people to fear becoming disease vectors (e.g., children or sickly-looking people). ${ }^{11}$ During previous pandemics and outbreaks, such as the SARS outbreak, shunning, ostracism, and avoidance were common. We have not learned the lesson of pandemic-related stigmatization of healthcare workers. It is not enough to congratulate healthcare professionals. Precise, sensible public education campaigns about the risks that healthcare workers pose to the public are needed. ${ }^{11}$

In the multivariate linear regression model, we found that workplace type was associated with stigmatization among healthcare workers. Healthcare workers who work in hospitals had higher stigma scores than those who work in non-hospital. A possible explanation for this finding is that the hospital is a place to treat COVID-19 patients with severe symptoms. Since the beginning of the COVID-19 pandemic, healthcare workers have been under heavy workload conditions worldwide, especially in hospitals. Limited resources, longer hours, sleep, work-life balance disturbances, and occupational hazards associated with COVID-19 exposure have led to adverse psychological outcomes among healthcare employees regarding post-traumatic stress, insomnia, anxiety, and depression. ${ }^{16,17}$ Healthcare workers, like everyone else, are vulnerable both to the disease itself and to rumors and incorrect information that necessarily increases their anxiety levels. Healthcare workers' anxiety was further impacted by growing stigmatization and loss of trust in their communities. ${ }^{18}$ All of this causes the internalized stigma of healthcare workers who work in hospitals to be higher than those who work in nonhospitals.

This study also found that the average stigma of doctors and other types of healthcare workers was not significantly different. Regarding the demography factors, healthcare workers' average stigma also was not significantly different. The pandemic has placed extraordinary levels of psychological stress on healthcare workers. Healthcare workers are exposed to high-demand settings for long hours, living in constant fear of disease exposure while separated from family and facing social stigmatization. A previous study in Japan found that both frontlines who have direct exposures to patients with COVID-19 daily and non-front line healthcare workers expressed similar concerns regarding the COVID-19 pandemic. ${ }^{19,20}$ Also, a previous study in Saudia Arabia found that demographic characteristics were not significantly associated with anxiety among healthcare workers. Psychological burdens such as anxiety can lead to feeling stigmatization among healthcare workers. In contrast, decreasing the emotional burden, especially social support, clear communication and distribution of tasks, flexible working hours, and the utilization of psychosocial and psychological help without stigmatization. $^{21}$

There is a large amount of information that can cause confusion and panic among residents. WHO describes this as an infodemic. ${ }^{22}$ Furthermore, The Indonesian government had identified more than 500 hoaxes related to the COVID-19 pandemic in social media. The government has made efforts to reduce hoaxes related to the COVID-19 pandemic through state-owned websites and social media. For example, 
www.covid19.go.id has a hoax buster feature to give accurate information regarding COVID-19 pandemics. In addition, the government gives some incentives for healthcare workers who work in health facilities during the COVID-19 pandemic through the Ministry of Health. However, this incentive has some constraints that make healthcare workers unable to get it periodically in the implementation. Furthermore, psychological counselors/counseling psychologists should regularly visit medical workers to listen to their stories and support them.

In conclusion, there was any stigmatization among healthcare workers in Greater Jakarta Metropolitan Area. The average stigma score was higher among healthcare workers who work in hospitals than those who work in non-hospitals. Some efforts should be made to reduce stigmatization among health workers, such as provide correct information to the public, equip healthcare workers with adequate personal protective equipment, and give incentives periodically to them. In addition, policymakers should make some regulations to prevent mental health, such as giving regular psychological counseling and selfhelp service among healthcare workers.

\section{Acknowledgment}

We thank the Center for Research and Development of Public Health efforts, NIHRD, MoH, for the permit and encouragement to conduct this online study amid the COVID-19 pandemic, March 2020. Finally, we thank all the respondents who voluntarily participated in this study.

\section{Funding}

Indonesia's government budget supported this study through the NIHRD, MoH of the Republic of Indonesia.

\section{Availability of the data and materials}

All data kept protected by the Data Management Section at the NIHRD, MoH, Republic of Indonesia.

\section{Author contribution}

Conceptualization: IS, N, NS, Sup. Data curation: IS, GV. Formal analysis: IS, GV. Funding acquisition: None. Methodology: IS, Sup, AR. Visualization: IS, AR, Writing - original draft: IS, AR, N, Sup, IBM, NS, Sud. Writing - review and editing: IS, N, AR, Sup, IBM, NS, Sud.

\section{Competing interest}

We declare that there is no competing interest in this study.

\section{REFERENCES}

1. World Health Organization. WHO DirectorGeneral's opening remarks at the Mission briefing on COVID-19 - 12 March 2020 [Internet]. 2020. [cited 2020 Apr 30]. Available from: https://www.who.int/ $\mathrm{dg} /$ speeches/detail/who-director-general-s-openingremarks-at-the-mission-briefing-on-covid-19---12march-2020

2. Gorbiano MI. BREAKING: Jokowi announces Indonesia's first two confirmed COVID-19 cases. The Jakarta Post [Internet]. 2020 Mar 2 [cited 2020 Apr 30]. Available from: https://www.thejakartapost. com/news/2020/03/02/breaking-jokowi-announcesindonesias-first-two-confirmed-covid-19-cases.html

3. Firman T, Fahmi FZ. The privatization of metropolitan Jakarta's (Jabodetabek) urban fringes: The early stages of "post-suburbanization" in Indonesia. J Am Plan Assoc. 2017;83(1):68-79.

4. Kementerian Kesehatan RI. Infeksi Emerging Kementerian Kesehatan [Internet]. 2020. [cited 2020 Apr 2]. Available from: https://covid19.kemkes. go.id/. Indonesian.

5. Turner-Musa J, Ajayi O, Kemp L. Examining social determinants of health, stigma, and COVID-19 disparities. Healthcare. 2020;8(2):68.

6. Organization WH. A guide to preventing and addressing social stigma associated with COVID-19. Vol. 24, Retrieved May. 2020.

7. Bhattacharya P, Banerjee D, Rao TSS. The "untold" side of COVID-19: social stigma and its consequences in India. Indian J Psychol Med. 2020;42(4):382-6.

8. Bai Y, Lin CC, Lin CY, Chen JY, Chue CM, Chou P. Survey of stress reactions among health care workers involved with the SARS outbreak. Psychiatr Serv. 2004;55(9):1055-7.

9. Koh D, Lim MK, Chia SE, Ko SM, Qian F, Ng V, et al. Risk perception and impact of severe acute respiratory syndrome (SARS) on work and personal lives of healthcare workers in Singapore what can we learn?. Med Care. 2005;43:676-82.

10. Ramaci T, Barattucci M, Ledda C, Rapisarda V. Social Stigma during COVID-19 and its impact on HCWs outcomes. Sustainability. 2020;12(9):3834.

11. Taylor S, Landry CA, Rachor GS, Paluszek MM, Asmundson GJG. Fear and avoidance of healthcare workers: an important, under-recognized form of stigmatization during the COVID-19 pandemic. J Anxiety Disord. 2020;75:102289.

12. Fox AB, Earnshaw VA, Taverna EC, Vogt D. Conceptualizing and measuring mental illness stigma: the mental illness stigma framework and critical 
review of measures. Stigma Heal. 2018;3(4):348.

13. Baldassarre A, Giorgi G, Alessio F, Lulli LG, Arcangeli G, Mucci N. Stigma and discrimination (SAD) at the time of the SARS-CoV-2 pandemic. Int J Environ Res. Public Health. 2020;17(17):6341.

14. Villa S, Jaramillo E, Mangioni D, Bandera A, Gori A, Raviglione MC. Stigma at the time of the COVID-19 pandemic. Clin Microbiol Infect. 2020;26(11):1450-2.

15. Kompas. Rawat pasien Covid-19, tenaga medis diusir dari kos hingga harus menginap [Internet]. 2020 [cited 2021 Apr 2]. Available from: https://megapolitan. kompas.com/read/2020/03/25/14090911/rawatpasien-covid-19-tenaga-medis-diusir-dari-koshingga-harus-menginap?page $=$ all. Indonesian .

16. Talaee N, Varahram M, Jamaati H, Salimi A, Attarchi M, Kazempour Dizaji M, et al. Stress and burnout in health care workers during COVID-19 pandemic: validation of a questionnaire. J Public Health (Bangkok). 2020; June 6:1-6.

17. Lasalvia A, Amaddeo F, Porru S, Carta A, Tardivo S, Bovo C, et al. Levels of burn-out among healthcare workers during the COVID-19 pandemic and their associated factors: a cross-sectional study in a tertiary hospital of a highly burdened area of north-east Italy. BMJ Open. 2021;11(1):e045127.

18. Schwartz J, King CC, Yen MY. Protecting health care workers during the COVID-19 coronavirus outbreaklessons from Taiwan's SARS response. Clin Infect Dis. 2020;71(15):858-60.

19. WHO. Keep health workers safe to keep patients safe: WHO. News release. 2020;17.

20. Sahashi Y, Endo H, Sugimoto T, Nabeta T, Nishizaki $\mathrm{K}$, Kikuchi A, et al. Worries and concerns among healthcare workers during the coronavirus 2019 pandemic: a web-based cross-sectional survey. Humanit Soc Sci Commun. 2021;8(1):1-8.

21. Alzaid EH, Alsaad SS, Alshakhis N, Albagshi D, Albesher R, Aloqaili M. Prevalence of COVID19-related anxiety among healthcare workers: a cross-sectional study. J Fam Med Prim care. 2020;9(9):4904.

22. Cinelli M, Quattrociocchi W, Galeazzi A, Valensise CM, Brugnoli E, Schmidt AL, et al. The covid-19 social media infodemic. Sci Rep. 2020;10(1):1-10. 